\title{
ANALISIS BEBAN KERJA PETANI PADA PENGOPERASIAN KNAPSACK SPRAYER
}

\section{FARMER WORKLOAD ANALYSIS ON KNAPSACK SPRAYER'S OPERATION}

\author{
Raizummi Fil'aini1 ${ }^{\bowtie}$, Tri Novita Sari ${ }^{2}$ \\ ${ }^{1}$ Department of Biosystems Engineering, Institut Teknologi Sumatera \\ ${ }^{2}$ Department of Industrial Engineering, University of Indraprasta PGRI \\ ${ }^{\square}$ Komunikasi penulis, email : raizummi.filaini@tbs.itera.ac.id \\ DOI:http://dx.doi.org/10.23960/jtep-lv9i2.131-139
}

Naskah ini diterima pada 26 Mei 2020; revisi pada 19 Juni 2020;

disetujui untuk dipublikasikan pada 20 Juni 2020

\begin{abstract}
Controlling pest and disease in agriculture is often carried out chemically using sprayer, one of them is a semi otomatic knapsack sprayer. The source of power and controlling of this equipment comes from man power. The operator must pump the liquid contained in the tank and spray it on the plants. This often causes muscle fatigue among workers. Therefore, analysis is needed related to the workload of farmers when applying knapsack sprayer. Workload analysis is done by recording the heart rate of male and female farmers. The tool used in the measurement is the Heart Rate Monitor (HRM). Measurements were made twice, namely measurements during calibration using the step test method and measurements in the field during spraying activity. The purpose of this study is to determine the qualitative workload (fatigue level) and quantitative workload (work energy consumption). The results showed that women had higher levels of fatigue than men, while their energy consumption did not differ significantly. The application of knapsack sprayer in the Wedung sub-district is more suitable for men.
\end{abstract}

Keywords: energy consumption, gender, knapsack sprayer, pest and plant diseases control, workload

\begin{abstract}
ABSTRAK
Pengendalian hama dan penyakit pertanian sering dilakukan secara kimia dengan menggunakan sprayer, salah satunya adalah sprayer semi-otomatis (knapsack sprayer). Sumber tenaga dan kendali pada knapsack sprayer berasal dari tenaga manusia. Operator harus memompa cairan yang terdapat pada tangki dan menyemprotkannya ketanaman. Hal ini sering kali menyebabkan kelelahan otot di antara para pekerja. Oleh karena itu, dibutuhkan analisis terkait beban kerja petani saat pengaplikasian knapsack sprayer. Analisis beban kerja dilakukan dengan merekam denyut jantung petani laki-laki dan perempuan. Alat yang digunakan dalam pengukuran adalah Heart Rate Monitor (HRM). Pengukuran dilakukan dua kali, yaitu pengukuran saat kalibrasi dengan menggunakan metode step test dan pengukuran di lapang saat aktivitas penyemprotan. Tujuan dari penelitian ini adalah untuk menentukan beban kerja kualitatif (tingkat kejerihan) dan kuantitatif (konsumsi energi kerja). Hasil penelitian menunjukkan bahwa perempuan memiliki tingkat kejerihan berat hingga luar biasa berat, sedangkan laki-laki memiliki tingkat kejerihan kerja sedang hingga berat, sedangkan laju konsumsi energi laki-laki adalah $3.52 \mathrm{kkal} /$ menit dan perempuan $3.22 \mathrm{kkal} /$ menit. Dari hasil tersebut, dapat disimpulkan bahwa pengaplikasian knapsack sprayer di kecamatan Wedung lebih cocok dilakukan oleh laki-laki.
\end{abstract}

Kata Kunci: beban kerja, jenis kelamin, knapsack sprayer, konsumsi energi, pengendalian hama dan penyakit tanaman

\section{PENDAHULUAN}

Komoditas paling penting dan strategis di Indonesia adalah padi. Komoditas tersebut merupakan makanan pokok bagi $80 \%$ masyarakat Indonesia (Syuaib, 2016), sehingga peningkatan produktivitas padi menjadi hal yang sangat penting. Berdasarkan data BPS (2019) produktivitas padi sawah di Jawa Tengah berada pada urutan kedua setelah Jawa Barat yaitu 
sebesar 57.53 kuintal/ha. Penanganan kegiatan pertanian yang tepat, baik pada fase budidaya maupun pascapanen, berpengaruh terhadap kualitas dan kuantitas produk pertanian yang dihasilkan (Marpaung et.al., 2019). Terdapat beberapa upaya yang dapat dilakukan untuk peningkatan nilai produktivitas padi secara berkelanjutan, salah satunya yaitu dengan melakukan pengendalian hama dan penyakit tanaman.

Serangan hama dan penyakit merupakan salah satu faktor penghambat dalam budidaya pertanian. Kerugian yang dapat ditimbulkan yaitu, menurunnya hasil panen atau bahkan dapat menyebabkan gagal panen, sehingga dibutuhkan pengendalian yang baik. Pengendalian hama dan penyakit tanaman sering dilakukan dengan tiga cara, yaitu: secara biologis, mekanis, dan kimiawi. Namun, di Indonesia paling sering dilakukan dengan cara kimiawi. Pengendalian secara kimia dilakukan dengan menyemprotkan bahan kimia dan obat-obatan yang dapat mencegah atau mengurangi hama dan penyakit tanaman dengan mengaplikasikan sprayer.

Pengaplikasian sprayer dilakukan dengan menggunakan tenaga manusia. Sprayer dengan tenaga manusia terdiri dari sprayer otomatis dan sprayer semi-otomatis atau yang biasa dikenal dengan knapsack sprayer. Knapsack sprayer banyak dijumpai di Kecamatan Wedung, Kabupaten Demak, Jawa Tengah dan beberapa daerah lainnya di Indonesia dengan kapasitas volume tangki sebesar 15 hingga 20 liter. Penggunaan alat pertanian tersebut, sering digunakan oleh petani lokal dalam pengendalian hama dan penyakit pada tanaman karena relatif mudah dalam pengaplikasiannya.

Aplikasi knapsack sprayer cukup menguras tenaga, dimana dalam pengoperasiannya operator berperan sebagai pengendali dan sumber tenaga utama, sehingga kerap kali menimbulkan beban kerja fisik pada operatornya. Beban kerja fisik dapat dilihat ketika pekerja melakukan pekerjaannya dan dapat dianalisis dengan pendekatan fisiolosi kerja. Fisiologi kerja adalah kondisi yang disebabkan beban atau tekanan eksternal saat bekerja. Indikatornya meliputi pernapasan, suhu tubuh, aktivitas otot, dan denyut jantung (Syuaib, 2003).

Denyut jantung merupakan salah satu indikator fisiologi kerja yang dapat diukur dengan mudah di lapang. Pengukuran ini dilakukan menjadi dua bagian, yaitu pengukuran denyut jantung kalibrasi dan pengukuran denyut jantung kerja. Hasil dari pengukuran denyut jantung yang relatif tinggi cenderung mencerminkan beban fisiologi dibandingkan beban mental (Fil'aini, 2017).

Beban kerja fisik yang terlalu berat akan menimbulkan kelelahan yang dapat terakumulasi. Kelelahan inilah yang pada akhirnya akan menyebabkan seseorang merasa sakit atau bahkan mengalami cedera. Untuk itu, perlu dilakukan pengukuran besar konsumsi energi (beban kerja kuantitatif) dan tingkat kejerihan (beban kerja kualitatif) pada pengguna knapsack sprayer dengan mengukur denyut jantung saat penyemprotan (Syuaib etal, 2012). Dengan mengetahui besarnya beban kerja operator, diharapkan operator dapat lebih memperhatikan lagi kenyamanan saat bekerja.

Faktor manusia sangat berpengaruh terhadap produktivitas kerja. Laki-laki dan perempuan memiliki tingkat produktivitas dan kapasitas yang berbeda-beda tergantung jenis pekerjaan yang dikerjakan. Oleh sebab itu, perlu dilakukan pengukuran konsumsi energi kerja dengan membandingkan besarnya konsumsi energi dengan kapasitas lapang dan konsumsi larutan per tangkinya baik untuk operator laki-laki maupun perempuan.

Penelitian kali ini bertujuan untuk mengukur beban kerja kuatitatif dan kualitatif (tingkat kejerihan) petani pengguna knapsack sprayer, mengukur konsumsi energi kerja (kkal/ha dan $\mathrm{kkal}$ tangki) operator dalam pengoperasian knapsack sprayer, dan membandingkannya antara petani laki-laki dan perempuan.

\section{BAHAN DAN METODA}

Kabupaten Demak merupakan salah satu kabupaten di Jawa Tengah yang memiliki luas lahan sawah irigasi terluas ketiga, yaitu setelah Kabupaten Brebes dan Cilacap (Kementerian 
Pertanian, 2017), sehingga pengambilan data lapang dilakukan di Kecamatan Wedung, Kabupaten Demak. Analisis data dilakukan di laboratorium Ergonomika, TMB, FATETA, IPB. Adapun alat dan bahan yang digunakan dalam penelitian, yaitu: heart rate monitor (HRM), Heart Rate Monitor Interface, dan digital metronome. Subjek yang akan diteliti merupakan petani di Kecamatan Wedung yang dalam kondisi sehat dan terbiasa melakukan pekerjaan dengan menggunakan knapsack sprayer. Penyemprotan berlangsung dengan menggunakan larutan insektisida untuk membunuh hama yang menyerang tanaman, penyemprotan dilakukan pada pagi hari, yaitu pukul 7.00-10.00 WIB.

Tenaga kerja atau petani memainkan peranan penting dalam pertanian di Indonesia dan tenaga manusia pada umunya masih dominan digunakan dalam kegiatan budidaya (Syuaib, 2015), salah satunya pengoperasian knapsack sprayer, baik dari segi tenaga maupun kontrol terhadap sebaran droplet dari sprayer. Sprayer umumnya dioperasikan oleh petani laki-laki dan perempuan. Dalam penelitian ini, subjek yang diukur terdiri dari 4 orang laki-laki dan 4 orang perempuan.

Penelitian dibagi menjadi tiga tahap, yaitu penelitian pendahuluan, pengambilan data, dan pengolahan data. Pada penelitian pendahuluan dilakukan peninjauan lokasi, pengamatan kegiatan dan sistem kerja, penyusunan metode pengambilan data yang sesuai, penentuan subjek, serta penjelasan pengambilan data. Pengambilan data di lapang meliputi data denyut jantung baik saat kalibrasi dengan metode step test (Gambar 1) maupun saat penyemprotan berlangsung (Gambar 2), pengukuran fisik tubuh, kapasitas lapang, dan konsumsi larutan insektisida. Pengukuran denyut jantung pekerja dilakukan dengan menggunakan Heart Rate Monitor (HRM). Pengukuran kalibrasi bertujuan untuk mengetahui kolerasi peningkatan denyut jantung terhadap pembebanan yang diberikan. Pembebanan diberikan secara bertingkat dimulai dari 15 siklus/menit, 20 siklus/menit, dan 25 siklus/menit (Kastaman dan Herodian, 1998).

Pada tahap pengolahan data pertama kali dilakukan pengukuran nilai BME dengan menggunakan Persamaan Du' Bois (Syuaib, 2003):

$$
A=H^{0,725} *_{w} 0,425 * 0,007246
$$

Dimana, A merupakan luas permukaan tubuh $\left(\mathrm{m}^{2}\right)$, $\mathrm{H}$ adalah tinggi badan $(\mathrm{cm})$, dan $w$ adalah berat badan $(\mathrm{kg})$.

Dari hasil perhitungan luasan tubuh dengan menggunakan Persamaan 1, nilai BME bisa ditentukan dengan menggunakan tabel konversi yang ditunjukan pada Tabel 1. Selanjutnya memindahkan hasil rekaman data denyut jantung

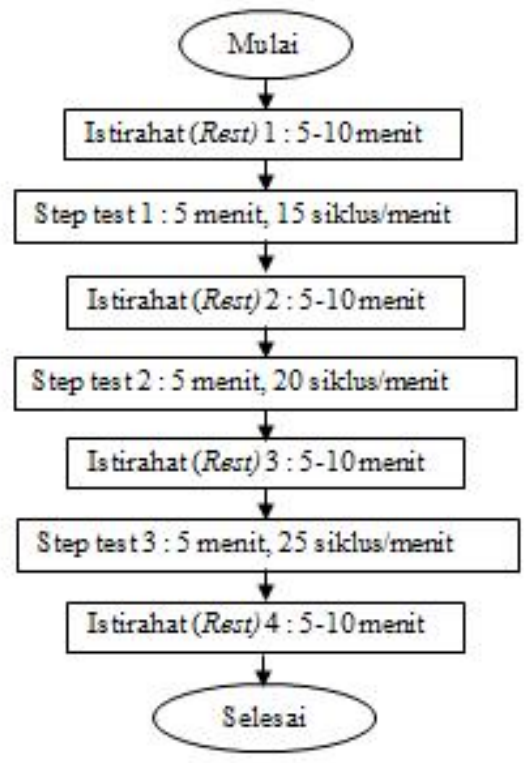

Gambar 1. Tahapan Pengukuran Denyut Jantung Kalibrasi 


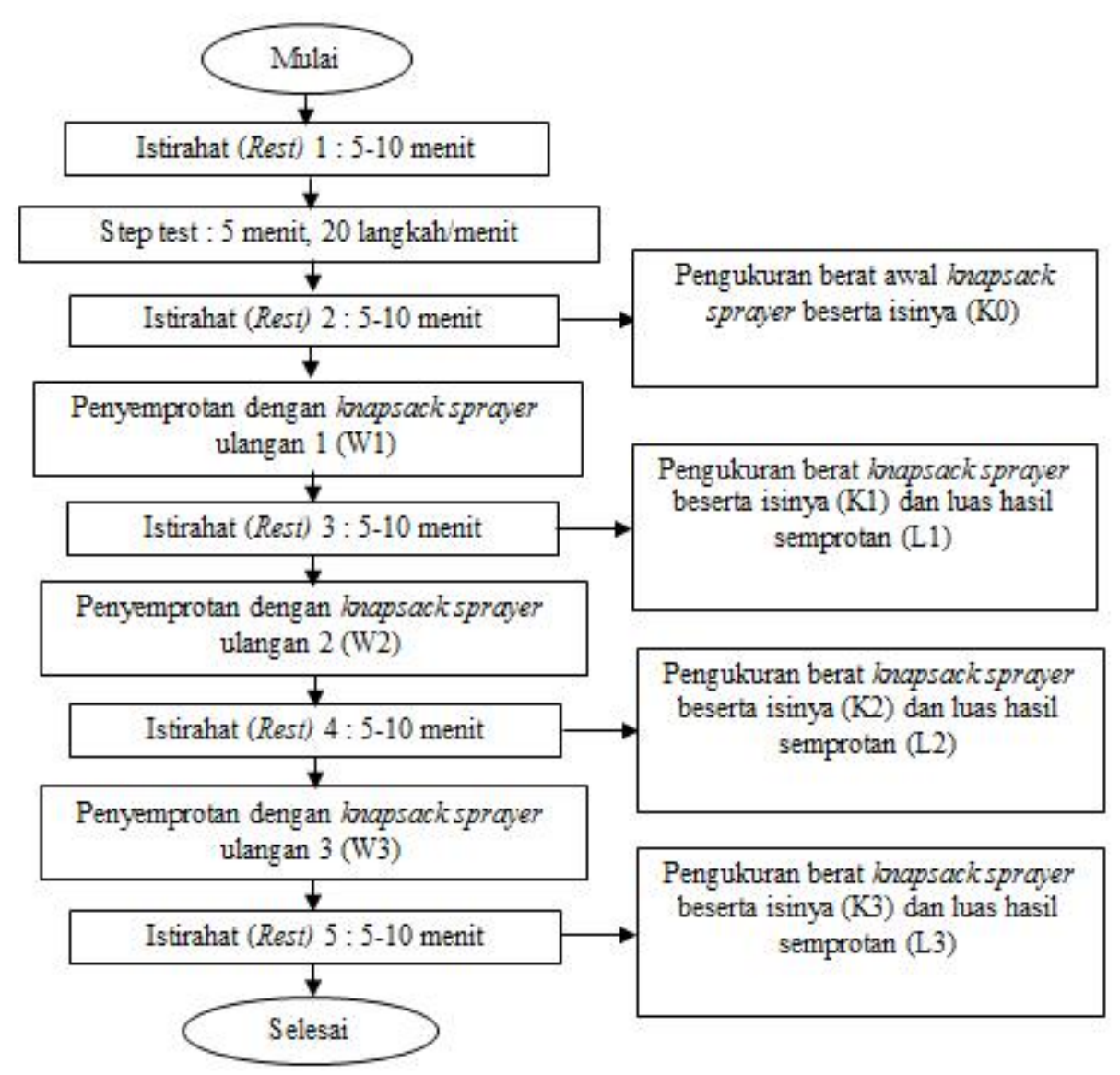

Gambar 2. Tahapan Pengukuran Denyut Jantung Saat Kerja

(HR) ke komputer dengan menggunakan HR Monitor Interface untuk diolah dan dibuat grafik.

Subjektivitas nilai denyut jantung yang umumnya dipengaruhi faktor personal, psikologis dan lingkungan, maka untuk menghindari hal tersebut perhitungan nilai HR harus dinormalisasi dengan cara membandingkan nilai $\mathrm{HR}$ relatif saat bekerja dan nilai HR saat istirahat (Persamaan 2), sehingga diperoleh nilai (Increase Ratio of Heart Rate) IRHR dan kategori pekerjaan berdasarkan nilai IRHR tersebut dapat dilihat pada Tabel 2.

$$
I R H R=\frac{H R_{W o r k}}{H R_{\operatorname{Re}} s t}
$$

Dimana, HR work adalah denyut jantung kerja (denyut/menit), HR rest adalah denyut jantung saat istirahat (denyut/menit), dan IRHR adalah tingkat kenaikan denyut jantung (Increase Ratio of Heart Rate).

Untuk menghitung konsumsi energi step test digunakan Persamaan 3 (Herodian et al, 2007).

$$
W E C_{S T}=\frac{w * g * 2 f * h}{\left(4,2 * 10^{3}\right)}
$$

Dimana, $\mathrm{WEC}_{\mathrm{ST}}$ adalah Work Energy Cost step test (kkal/menit), $w$ adalah berat badan (kg), $g$ adalah percepatan grafitasi $\left(\mathrm{m} / \mathrm{s}^{2}\right)$, f adalah frekuensi step test (siklus/menit), dan h adalah tinggi bangku step test $(\mathrm{m})$.

Nilai WEC pada saat beraktivitas $\left(\mathrm{WEC}_{\text {WoRK }}\right.$ ) diperoleh dengan membuat grafik hubungan antara $\mathrm{WEC}_{\mathrm{ST}}$ dengan nilai IRHR $\mathrm{ST}_{\mathrm{ST}}$ dan selanjutnya didapatkan nilai kolerasinya. Dari grafik tersebut diperoleh persamaan daya $(\boldsymbol{y}=\boldsymbol{a x}+\boldsymbol{b})$, dimana nilai $\boldsymbol{y}$ adalah nilai IRHR dan $\boldsymbol{x}$ adalah nilai WEC. Dari masing-masing subjek akan mempunyai persamaan yang berbeda-beda.

Setelah melakukan pekerjaan (Gambar 2) maka selanjutnya dicari nilai IRHR saat bekerja $\left(\right.$ IRHR $_{\text {work }}$ ) dengan menggunakan Persamaan 2. Nilai IRHR $_{\text {WORK }}$ inilah yang nantinya akan disubtitusi ke dalam persamaan daya $(\boldsymbol{y}=\boldsymbol{a} \boldsymbol{x}+\boldsymbol{b})$, 
Tabel 1. Konversi BME Ekivalen $\dot{\boldsymbol{V}} \mathrm{O}_{2}$ Berdasarkan Luas Permukaan Tubuh (ml/menit)

\begin{tabular}{ccccccccccc}
\hline $\begin{array}{c}1 / 100 \\
\mathrm{~m}^{2}\end{array}$ & 0 & 1 & 2 & 3 & 4 & 5 & 6 & 7 & 8 & 9 \\
\hline 1.1 & 136 & 137 & 138 & 140 & 141 & 142 & 143 & 145 & 146 & 147 \\
1.2 & 148 & 150 & 151 & 152 & 153 & 155 & 156 & 157 & 158 & 159 \\
1.3 & 161 & 162 & 162 & 164 & 166 & 167 & 168 & 169 & 171 & 172 \\
1.4 & 173 & 174 & 176 & 177 & 178 & 179 & 181 & 182 & 183 & 184 \\
1.5 & 186 & 187 & 188 & 189 & 190 & 192 & 193 & 194 & 195 & 197 \\
1.6 & 198 & 199 & 200 & 202 & 203 & 204 & 205 & 207 & 208 & 209 \\
1.7 & 210 & 212 & 213 & 214 & 215 & 217 & 218 & 219 & 220 & 221 \\
1.8 & 223 & 224 & 225 & 226 & 228 & 229 & 230 & 231 & 233 & 234 \\
1.9 & 235 & 236 & 238 & 239 & 240 & 241 & 243 & 244 & 245 & 246 \\
\hline
\end{tabular}

Keterangan: Subjek perempuan nilai $\dot{V} \mathrm{O}_{2}$ harus dikalikan 0.95 (Syuaib, 2003)

Tabel 2. Kategori Pekerjaan Berdasarkan IRHR (Syuaib, 2003)

\begin{tabular}{lc}
\hline Kategori & Nilai IRHR \\
\hline Ringan & $1.00=$ IRHR $<1.25$ \\
Sedang & $1.25=$ IRHR $<1.50$ \\
Berat & $1.50=$ IRHR $<1.75$ \\
Sangat berat & $1.75=$ IRHR $<2.00$ \\
Luar biasa berat & $2.00=$ IRHR \\
\hline
\end{tabular}

sehingga didapat nilai WEC saat bekerja $\left(\mathrm{WEC}_{\text {WORK }}\right)$ dalam kkal/menit.

Nilai BME dapat digunakan untuk menghitung nilai TEC dengan menjumlah nilai BME dengan nilai $\mathrm{WEC}_{\mathrm{WoRK}^{\prime}}$ sehingga didapatkan nilai TEC dalam kkal/menit (Bridger, 2003). Berat badan seseorang sangat mempengaruhi jumlah energi total yang dimilikinya, sehingga dalam terminologi kebutuhan energi kerja, terdapat istilah Total Energy Cost per Weight (TEC'), TEC' merupakan nilai dari TEC yang dinormalisasi untuk mengetahui nilai beban kerja objektif yang diterima oleh seseorang saat melakukan kerja. Nilai TEC' didapat dengan membagi nilai TEC dengan berat badan subjek (kg), sehingga nilai TEC' yang diperoleh dalam satuan $\mathrm{kkal} / \mathrm{kg}$. menit.

Nilai kapasitas lapang $\left(\mathrm{m}^{2} /\right.$ menit) dan konsumsi larutan (liter/menit) dapat dihitung dengan membandingkan antara luas lahan $\left(\mathrm{m}^{2}\right)$ yang berhasil disemprot dan volume larutan (liter) yang terpakai dengan waktu (menit) yang dibutuhkan. Untuk dapat mengukur volume larutan dalam sekali pengoperasian dapat diketahui dengan mengukur berat knapsack sprayer beserta isinya lalu dikurangi dengan berat knapsack sprayer setelah digunakan, sehingga didapatkan berat larutan yang dikonsumsi (kg) agar dapat dikonversi menjadi liter. Selanjutnya nilai kapasitas lapang dan konsumsi larutan dibandingkan dengan nilai TEC agar didapat nilai konsumsi energi dalam kkal/ ha dan kkal/tangki (20 liter).

\section{HASIL DAN PEMBAHASAN}

Beban kerja merupakan respon tubuh yang dirasakan oleh seseorang akibat kerja atau stress yang diterimanya. Beban kerja dapat dibagi menjadi dua, yaitu beban kerja kualitatif (tingkat kejerihan) dan beban kerja kuantitatif (besar konsumsi energi). Tahap pengukuran beban kerja kuantitatif dimulai dengan mengukur karakteristik fisik subjek meliputi usia, jenis kelamin, berat badan, serta tinggi badan. Dengan menggunakan data karakteristik tersebut diperoleh nilai BME (Tabel 3) yang berbeda setiap induvidu. Semakin besar berat badan seseorang atau semakin besar tinggi seseorang, maka luas permukaan tubuh seseorang juga akan semakin luas, sehingga nilai BME yang diperoleh juga akan semakin besar. 
Pengukuran denyut jantung dimulai dengan mengukur denyut jantung saat kalibrasi dengan metode step test. Step test dilakukan untuk mengetahui kolerasi antara ratio kenaikan denyut jantung (IRHR ${ }_{\mathrm{ST}}$ ) dengan peningkatan beban kerja $\left(\mathrm{WEC}_{\mathrm{ST}}\right)$. Dari hubungan antara nilai $\mathrm{IRHR}_{\mathrm{ST}}$ dan $\mathrm{WEC}_{\mathrm{ST}}$, didapatkan persamaan daya yang diperoleh dari garis linier pada Gambar 3. Nilai $\boldsymbol{y}$ dapat dicari setelah nilai-nilai $\boldsymbol{x}$ diketahui dan ditentukan terlebih dahulu, begitu pula sebaliknya. Dalam hal ini, nilai $\boldsymbol{y}$ yang akan disubtitusikan ke persamaan tersebut merupakan nilai IRHR pada saat bekerja $\left(\right.$ IRHR $\left._{\text {WORK }}\right)$.

Perubahan nilai IRHR $_{\mathrm{ST}}$ terhadap $\mathrm{WEC}_{\mathrm{ST}}$ dapat dilihat dari slope atau kemiringan garis. Slope garis dapat dilihat dari nilai $\boldsymbol{a}$ pada persamaan $\boldsymbol{y}=\boldsymbol{a} \boldsymbol{x}+\boldsymbol{b}$. Semakin curam kemiringan grafik maka semakin besar perubahan nilai IRHR terhadap nilai WEC, dan begitu sebaliknya. Jadi, penambahan beban sedikit akan menyebabkan peningkatan IRHR yang cukup besar. Nilai slope (a) paling besar tedapat pada subjek P2, yaitu sebesar 0.6522. Hal ini menandakan bahwa penambahan beban step test menyebabkan meningkatnya nilai IRHR menjadi lebih berat dari sebelumnya.

Pengambilan data denyut jantung saat aktivitas penyemprotan dilakukan dihari yang berbeda dari pengukuran kalibrasi. Setelah denyut jantung subjek saat aktivitas menyemprot diperoleh, maka dilakukan perhitungan nilai IRHR $_{\text {WORK }}$.

Klasifikasi tingkat kejerihan masing-masing subjek dapat dilihat dari nilai IRHR (Gambar 4). Tingkat kejerihan subjek laki-laki termasuk kedalam kategori kerja sedang hingga berat, sedangkan pada subjek perempuan berat hingga luar biasa berat, sehingga pekerjaan ini lebih melelahkan bagi subjek perempuan. Secara umum fisik laki-laki lebih kuat dibandingkan

Tabel 3. Karakteristik Fisik Subjek dan Nilai BME

\begin{tabular}{ccccccc}
\hline Subjek & $\begin{array}{c}\text { Usia } \\
\text { (tahun) }\end{array}$ & $\begin{array}{c}\mathbf{H} \\
\mathbf{( c m )}\end{array}$ & $\begin{array}{c}\mathbf{w} \\
\mathbf{( k g )}\end{array}$ & $\begin{array}{c}\mathbf{A} \\
\mathbf{( m 2 )}\end{array}$ & $\begin{array}{c}\dot{\mathbf{V}} \mathbf{O}_{2} \\
\text { (ml/menit) }\end{array}$ & $\begin{array}{c}\text { BME } \\
\text { (kkal/menit) }\end{array}$ \\
\hline P1 & 45 & 151 & 52 & 1.48 & 183 & 0.869 \\
P2 & 40 & 157 & 37 & 1.31 & 162 & 0.770 \\
P3 & 40 & 160 & 47 & 1.47 & 182 & 0.865 \\
P4 & 32 & 160 & 66 & 1.70 & 210 & 0.998 \\
\hline L1 & 43 & 157 & 61.5 & 1.63 & 202 & 1.010 \\
L2 & 52 & 170 & 58 & 1.69 & 209 & 1.045 \\
L3 & 46 & 165 & 52 & 1.57 & 194 & 0.970 \\
L4 & 49 & 172 & 50 & 1.60 & 198 & 0.990 \\
\hline
\end{tabular}

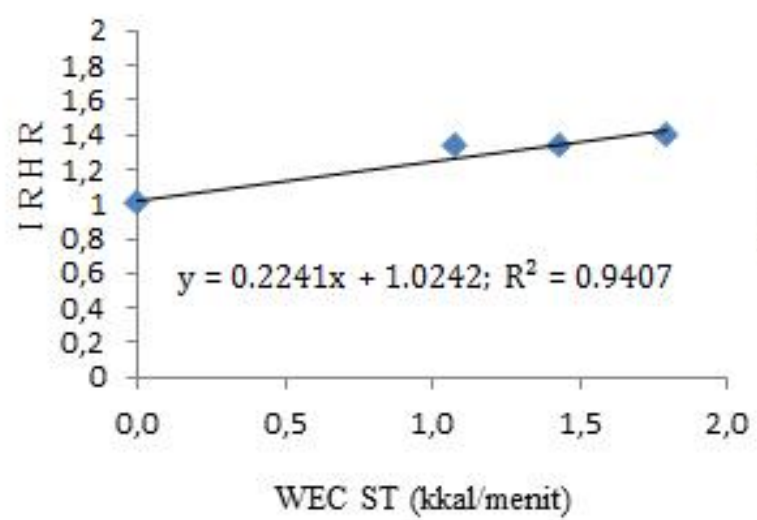

(a)

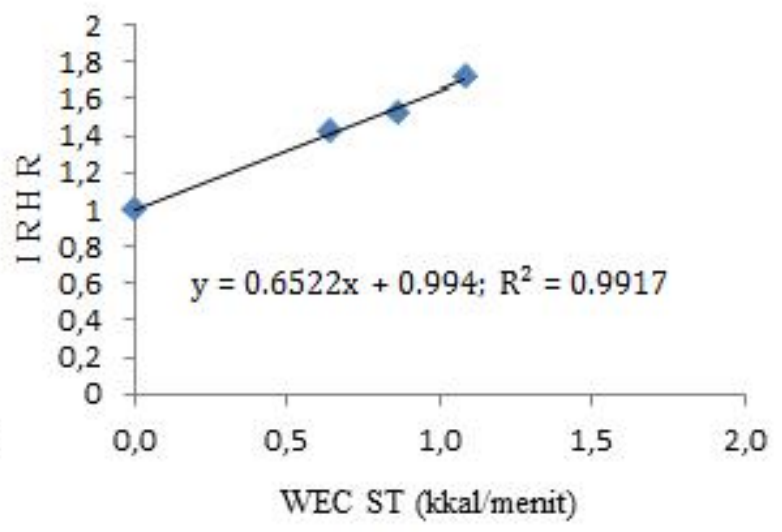

(b)

Gambar 3. Grafik Hubungan Antara IRHR ${ }_{\mathrm{ST}}$ dan $\mathrm{WEC}_{\mathrm{ST}}$ untuk (a) Subjek L1 dan (b) Subjek P2 

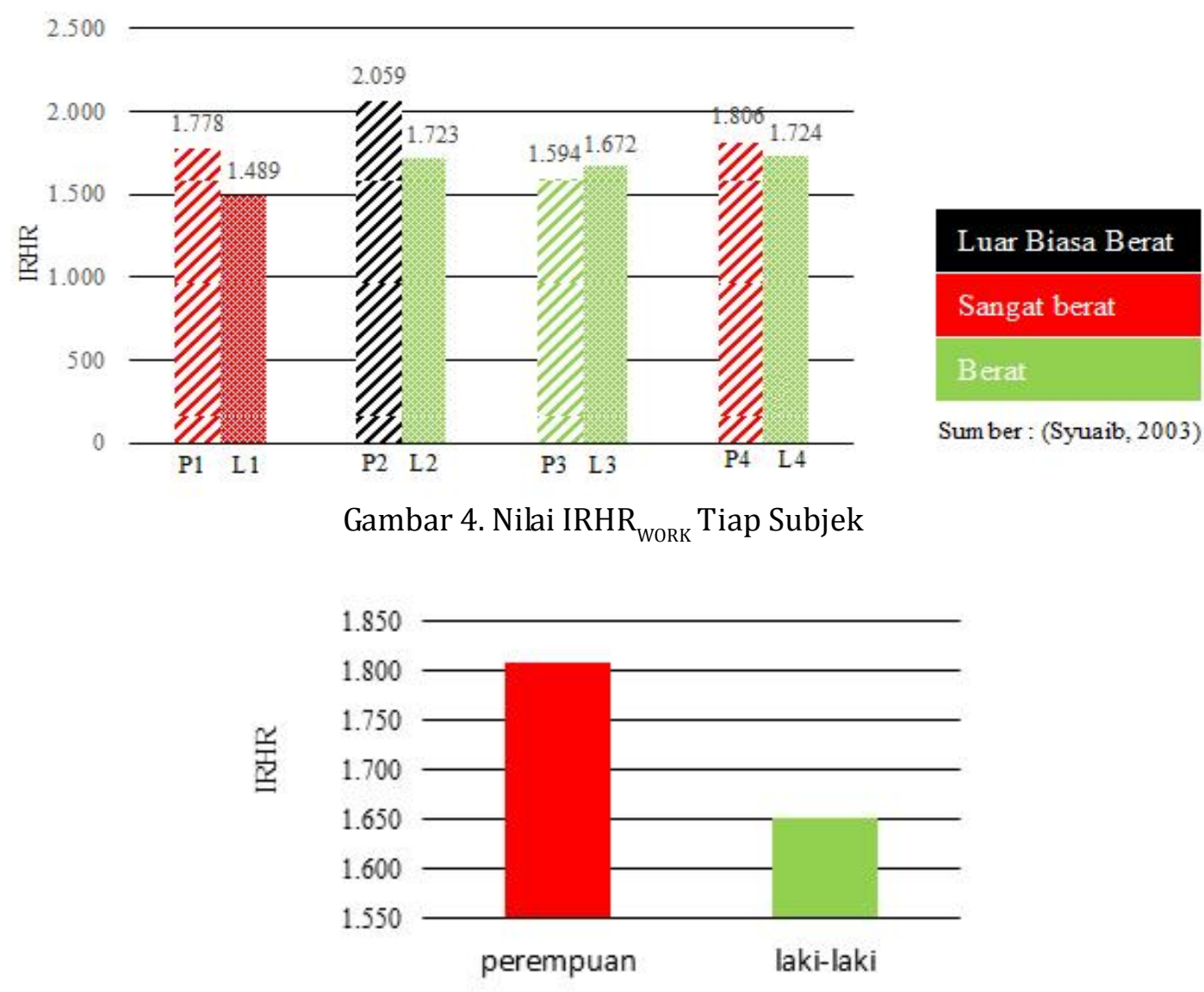

Gambar 5. Grafik Tingkat Kejerihan Rata-Rata Subjek

perempuan, sehingga kemampuan laki-laki dalam menerima beban juga lebih tinggi. Kategori tingkat kejerihan rata-rata subjek dapat dilihat pada Gambar 5 jika diklasifikasikan dengan mengacu pada Tabel 2 (Syuaib, 2003).

Konsumsi energi dari masing-masing subjek berbeda-beda sesuai dengan karakteristik tubuh subjek. Berat badan seseorang pada dasarnya juga menjadi beban bagi dirinya, sehingga untuk melakukan suatu pekerjaan yang relatif sama, seseorang dengan berat badan yang lebih besar secara umum akan mengkonsumsi energi yang lebih besar jika dibandingkan dengan seseorang yang memiliki berat badan yang kecil. Laju konsumsi energi masing-masing subjek dapat dilihat pada Tabel 4 .

Nilai WEC $_{\text {WORK' }}$ TEC, dan TEC' berbanding lurus, sehingga semakin tinggi nilai $\mathrm{WEC}_{\text {WoRK }}$ maka nilai TEC dan TEC' juga akan semakin tinggi. Setiap subjek melakukan pekerjaan yang sama, yaitu menyemprot tanaman padi dengan menggunakan knapsack sprayer. Namun, dapat dilihat pada Tabel 4, respon fisiologis dari masing-masing subjek berbeda-beda. Ada beberapa faktor yang mempengaruhi perbedaan tersebut diantaranya karakteristik dari tiap subjek, kemampuan fisiologis (kemampuan cardio-vaskuler/jantung dan serat otot) tiap subjek, serta pengaruh lingkungan fisik (suhu dan kelembaban).

Hasil analisis laju konsumsi energi total, menunjukan bahwa laki-laki lebih besar dibandingkan perempuan. Laki-laki memiliki laju konsumsi energi rata-rata sebesar $3.52 \mathrm{kkal} /$ menit, sedangkan perempuan sebesar $3.22 \mathrm{kkal} /$ menit. Artinya, laki-laki lebih banyak mengkonsumsi energi untuk kerja per satuan waktunya. Selain itu, data subjek perempuan memiliki simpangan baku lebih besar yaitu sebesar $0.64 \mathrm{kkal} /$ menit dan laki-laki hanya sebesar $0.3 \mathrm{kkal} /$ menit. Ada beberapa faktor yang mempengaruhi hal tersebut, yaitu: subjek perempuan memiliki tingkat keterbiasaan dan keterampilan yang berbeda, tidak semua subjek sering melakukan penyemprotan. Pada subjek 
laki-laki, hampir semuanya sudah terbiasa dan sering melakukan penyemprotan, sehingga nilainya tidak jauh berbeda. Selain itu, pada subjek laki-laki, luas permukaan tubuhnya juga lebih seragam dibandingkan subjek perempuan (Tabel 3).

Nilai IRHR $_{\text {WORK }}$ rata-rata (Gambar 5) subjek perempuan adalah 1.809 dan laki-laki sebesar 1.652. Tingkat kejerihan yang ditunjukan oleh nilai IRHR ${ }_{\text {woRk' }}$ pada subjek perempuan rata-rata relatif tinggi, namun laju konsumsi energi untuk perempuan lebih rendah dibandingkan laki-laki. Hal ini dapat saja terjadi, karena nilai IRHR hanya dihubungkan dengan kemampuan diri seseorang. Nilai IRHR mencerminkan beban kerja relatif terhadap kapasitas diri seseorang, selain itu juga terdapat perbandingan antara kerja dan istirahat, sedangkan laju konsumsi energi merupakan jumlah energi per satuan waktu yang dikeluarkan ketika seseorang melakukan aktivitas atau respon yang dikeluarkan oleh seseorang terhadap beban yang dirasakan. Sehingga pengeluaran energi yang sama memiliki dampak yang berbeda-beda untuk tiap subjeknya.
Nilai TEC' lebih seragam jika dibandingkan dengan nilai TEC, karena pada TEC' tidak ada pengaruh berat badan terhadap konsumsi energi. Untuk melakukan kerja yang sama secara umum akan mengkonsumsi energi yang sama pula. Hal inilah yang menyebabkan hasil TEC' tidaklah jauh berbeda antar subjeknya.

Pada penelitian ini, nilai konsumsi energi kerja per satuan unit kerja (kkal/ha) dan (kkal/tangki (20 liter)) dibutuhkan untuk mengetahui besarnya konsumsi energi terhadap output yang dihasilkan. Konsumsi energi kerja dihitung dengan membandingkan nilai TEC dengan luas lahan hasil semprotan per waktunya dan volume larutan per waktunya.

Berdasarkan Gambar 6 terlihat bahwa subjek perempuan mengeluarkan energi yang lebih banyak jika dibandingkan laki-laki untuk menyemprot 1 ha lahan dan mengkonsumsi 1 tangki larutan insektisida (20 L). Subjek perempuan rata-rata mengeluarkan 1000 kkal per satu ha, sedangkan untuk subjek laki-laki rata-rata hanya sebesar $527.5 \mathrm{kkal}$ per satu ha. Berdasarkan konsumsi larutan, subjek perempuan memiliki konsumsi energi 77.68 kkal per tangkinya, sedangkan untuk subjek laki-

Tabel 4. Laju Konsumsi Energi Saat Penyemprotan

\begin{tabular}{cccccc}
\hline Subjek & $\begin{array}{c}\text { Berat Badan } \\
\text { (kg) }\end{array}$ & $\begin{array}{c}\text { WEC work } \\
\text { (kkal/menit) }\end{array}$ & $\begin{array}{c}\text { BME } \\
\text { (kkal/menit) }\end{array}$ & $\begin{array}{c}\text { TEC } \\
\text { (kkal/menit) }\end{array}$ & $\begin{array}{c}\text { TEC' } \\
\text { (kkal/kg. menit) }\end{array}$ \\
\hline P1 & 52.0 & 3.06 & 0.87 & 3.93 & 0.08 \\
P2 & 37.0 & 1.63 & 0.77 & 2.40 & 0.06 \\
P3 & 47.0 & 2.25 & 0.86 & 3.11 & 0.07 \\
P4 & 66.0 & 2.44 & 0.99 & 3.43 & 0.05 \\
\hline \multicolumn{7}{c}{ Rata-rata } & & $3.22 \pm 0.64$ & 0.06 \\
\hline L1 & 61.5 & 2.07 & 1.01 & 3.08 & 0.05 \\
L2 & 58.0 & 2.70 & 1.05 & 3.75 & 0.06 \\
L3 & 52.0 & 2.61 & 0.97 & 3.58 & 0.07 \\
L4 & 50.0 & 2.68 & 0.99 & 3.67 & 0.07 \\
\hline \multicolumn{7}{r}{ Rata-rata } \\
\hline
\end{tabular}
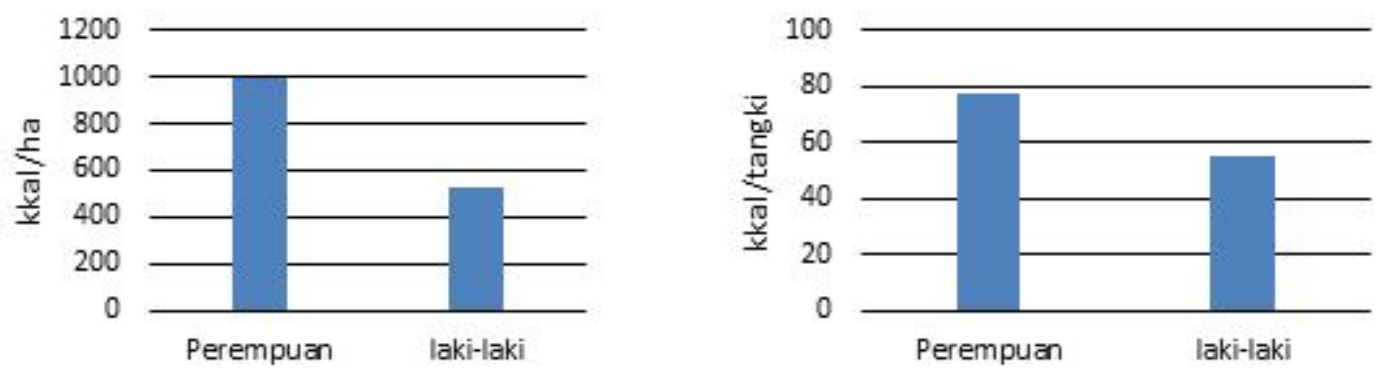

Gambar 6. Konsumsi Energi Kerja Subjek 
laki rata-rata hanya sebesar 55.33 kkal/tangki. Konsumsi energi kerja dari tiap subjek tidaklah sama. Hal ini biasanya tergantung dari keterampilan subjek dalam pengoperasian alat, tingkat keseringan subjek dalam mengoperasikan alat, keserasian antara subjek dan alat kerja yang digunakan, kesehatan subjek, jenis kelamin, serta usia subjek.

\section{KESIMPULAN}

Nilai TEC rata-rata subjek perempuan sebesar $3.22 \mathrm{kkal} /$ menit dan laki-laki sebesar $3.52 \mathrm{kkal} /$ menit. Secara umum nilai TEC perempuan lebih kecil dibandingkan laki-laki, artinya subjek perempuan mengkonsumsi energi untuk kerja per satuan waktu yang lebih sedikit. Nilai IRHR $_{\text {woRK }}$ rata-rata subjek perempuan sebesar 1.809 dan laki-laki 1.652, sehingga aktivitas penyemprotan dengan menggunakan knapsack sprayer bagi subjek perempuan tergolong kerja yang relatif berat. Konsumsi energi kerja yang dikeluarkan oleh subjek perempuan sebesar $1000 \mathrm{kkal} / \mathrm{ha}$ dan $77.68 \mathrm{kkal} /$ tangki, sedangkan laki-laki sebesar $527.5 \mathrm{kkal} / \mathrm{ha}$ dan $55.33 \mathrm{kkal} /$ tangki. Oleh karena itu, konsumsi energi kerja per satuan unit (kkal/ha dan kkal/tangki) yang dikeluarkan oleh subjek perempuan untuk menyemprot luasan lahan tertentu lebih besar dibandingkan laki-laki. Secara umum kegiatan penyemprotan dengan menggunakan knapsack sprayer lebih cocok dilakukan oleh subjek lakilaki.

\section{DAFTAR PUSTAKA}

Bridger RS. 2003. Introduction to Ergonomics. Taylor \& Francis. London \& New York.

Badan Pusat Statistik. 2019. Luas Panen, Produksi, dan Produktivitas Padi Menurut Provinsi 2018-2019. https:// www.bps.go.id/dynamictable/2019/04/ $15 / 1608 /$ luas-panen-produksi-danproduktivitas-padi-menurut-provinsi2018.html (diakses pada 15 Juni 2020).

Fil'aini R. 2017. Studi Ergonomika untuk Pemodelan Sistem Tata Kerja pada Produksi Beras yang Berkelanjutan. Tesis. Fakultas Teknologi Pertanian, IPB. Bogor.
Herodian S, Syuaib MF, Saulia L, Yamin M. 2007. Pengembangan Laboratorium Virtual Mata Kuliah Ergonomika Dan Keselamatan Kerja Berbasis E-Learning. Bogor: Ergonomika dan Elektronika Pertanian, TMB, IPB.

Kastaman R dan Herodian S. 1998. Studi Kalibrasi Data Pengukuran Beban Kerja dengan Menggunakan Metode Step Test dan Ergometer. Bul Keteknikan Pertanian 12(1): 35-45.

Kementerian Pertanian. 2017. Statistika Lahan Pertanian Tahun 2012-2016. Jakarta: Sekretariat Jenderal-Kementerian Pertanian. Pusat Data dan Sistem Informasi Pertanian.

Marpaung, D. S. S., Fil'aini R, Fahrani AC, Cahyani D, Sinaga A.O.Y. (2019). Physical changes of andaliman (Zanthoxylum Acanthopodium Dc.) in packaging during low-temperature storage. AGROINTEK. 13(2): 177-182.

Syuaib MF. 2003. Ergonomic Study on the Process of Mastering Tractor Operation. Disertasi. Tokyo University of Agricultural and Technology. Tokyo. Japan.

Syuaib MF, Herodian S, Hidayat DA, Fil'aini R, Sari TN, Putranti KA. 2012. Kajian Ergonomi untuk Penyempurnaan Sistem dan Produktivitas Panen Kelapa Sawit di PT. Astra Agro Lestari. Bogor: Fakultas Teknologi Pertanian, Institut Pertanian Bogor.

Syuaib MF. 2015. Anthropometric study of farm workers on Java Island, Indonesia, and its implications for design of farm tools and equipment. Applied Ergonomics. 51: 222235.

Syuaib MF. 2016. Sustainable Agriculture in Indonesia: Facts and challenges to keep growing in harmony with environment. Agricultural Engineering International: CIGR Journal. 18(2):170-184. 